\title{
INDONESIAN STANDARDIZED EXAMINATION IN ISLAMIC RELIGIOUS EDUCATION
}

\author{
Lian G. Otaya \\ State Islamic Institute (IAIN) Sultan Amai Gorontalo, Celebes, Indonesia \\ Jalan Gelatik no. 1, Gorontalo 96112 \\ Email: lian.otaya@yahoo.com
}

\begin{abstract}
This study aimed to determine the quality of Indonesian nationally standardized examination instrument (Soal Ujian Sekolah Berstandar Nasional/SUSBN) in Islamic religious education subjects (Pendidikan Agama Islam/PAI), on 2011/2012 academic year, in high school of Gorontalo City, Celebes, Indonesia. It was assessed from the aspect of qualitative analysis and quantitative analysis based on classical-modern test theory and iteman program. This is an ex post facto research. Data were collected by document analysis technique and used 215 sample from 1321 population of learners. The result shows that items of the question has a good validity level; the distribution of cognitive domain comprehenship enough; it reliability was stable; level of difficulty was categorized as fair; criteria different power are well accepted; effectiveness of detractors items are effective. However, on several points need revised in order to in line with the Regulation of the Minister of Religious Affairs and National Education Standards Agency.
\end{abstract}

Keywords: National standardized examination, Islamic religious education, Qualitative-quantitative analysis

\begin{abstract}
ABSTRAK
Penelitian ini bertujuan mengungkap kualitas instrument Soal Ujian Sekolab Berstandar Nasional (SUSBN) Mata Pelajaran Pendidikan Agama Islam (PAI) tabun akademik 2011/2012 di Kota Gorontalo, Sulawesi, Indonesia. Instrumen tersebut dianalisis secara kualitatif dan kuantitatif melalui teknik analisis item klasik, modern dan item program. Metode penelitian yang digunakan adalah expost facto. Data dikumpulkan melalui analisa dokumen. Peneliti mengumpulkan sampel sebanyak 215 yang diambil dari 1321 populasi pelajar di Kota Gorontalo. Hasil penelitian menunjukkan bahwa item soal ujian memiliki tingkat validiatas yang baik; sebaran domain kognitif cukup komprehensif; reliabilitasnya cukup konsisten dan ajeg; tingkat kesulitan cukup; daya pembeda pun bisa diterima. Berarti, kualitas instrumen ujian cukup baik. Namun demikian, pada beberapa poin perlu direvisi agar bisa digunakan untuk ujian akbir semester dan sesuai dengan Peraturan Menteri Agama (PMA) maupun Badan Standar Nasional Pendidikan (BSNP) Republik Indonesia.
\end{abstract}

Kata Kunci: Ujian berstandar nasional, Pendidikan Agama Islam, Analisis kualitatifkuantitatif 


\section{INTRODUCTION}

The quality of Indonesian nationally standardized examination instruments (SUSBN) in Islamic Religious Education Subjects (PAI) in Gorontalo City High School can be revealed by analyzing the items both qualitatively and quantitatively. Qualitative analysis was performed to assess the material, construction, and language items. Quantitative analysis is performed to determine the validity and reliability of items. So it measures the degree of difficulty, different power and the effectiveness of destractors items. To analyze sheets and answer keys, the study used the program iteman. When the instruments qualified reliable, level of difficulty faired, different power and destractor of items work properly, then the instruments have been a good quality.

Theoreticaly, a good assessment instrument must be able to measure something that should be measured (Mardapi, 2008, p. 93-94). The compilers should be recognized to various theories about composing of examinations instrument, such as classical and modern theories (Allen \& Yen, 1979). But in reality, the compilers of SUSBN-PAI-test in Gorontalo city paidless attention to it. Some items Indonesia Nationally PAI exam in Gorontalo city high school was less valid and reliable because of less clear and distinct. In fact, wholistic evaluation of the students is needed so that to the quality of PAItest is nationally standardized.

This study intends to proved the quality of items Nationally PAI-test in high school at Gorontalo City, and to give solution how to be improved. This research is an ex post facto, which investigating in the past events to determine the factors influenced these events. In this study, the researchers did not specifically manipulate the subject of research. Data collection were obtained by analyzing documents of test (documentary analysis), describing the events that have taken place, and considering the recent quality demands of PAI.

\section{FINDINGS AND ANALYSIS}

\section{Results of Qualitative Analysis}

The analysis showed that from 50 items, there are only two (2) questions which do not need to be revised, namely number 1 and 27 . That means there are 48 questions which need to be revised, namely number $2,3,4,5,6,7,8$, $9,10,11,12,13,14,15,16,17,18,19,20,21,22,23,24,26,28,29,30,31$, $32,33,34,35,36,37,38,39,40,41,42,43,44,45,46,47,48,49$, and 50 .

Items were revised covering aspects of material, construction and language. Generally, in the aspect of the material, there are three criteria are not compiled, namely; number 01 (suitability indicator), 02 (suitability of competence) and 03 (homogeneity and the logic). In the construction aspect, 
generally, there are four criteria are not compiled, namely; number 05 (about to be concise, clear and firm), 06 (should not lead to the correct answer), 07 (should not be a double negative meanings) and 08 (length of the answer should be relatively the same). In the aspect of language, generally, there are three criteria are not compiled, namely; number 11 (used a good and rightof Bahasa Indonesia), 12 (communicative) and 14 (not repeated the word/group of words/phrase which not have unity of sense).

2. Beside capable to read the Qur'an, we are also encouraged to be able to understand the meaning of the verse. Consider the following verse!

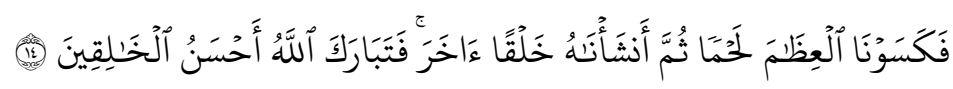

The correct translation for a piece of underlined verse is....
a. So blessed be Allah, the best to create
b. Sperm into a clot of congealed blood
c. And we made out of that lump bones
d. Then we made the clot a congealed blood flesh
e. Then We made out of it another creature

The criteria are not compiled, namely; Question was vague and contains a double negative statement (construction) and less communicative (language). The verse of the Qur'an in the question was not cited, so it is less communicative.

3. Notice verse 5 of Surah Al-Bayyinah below!

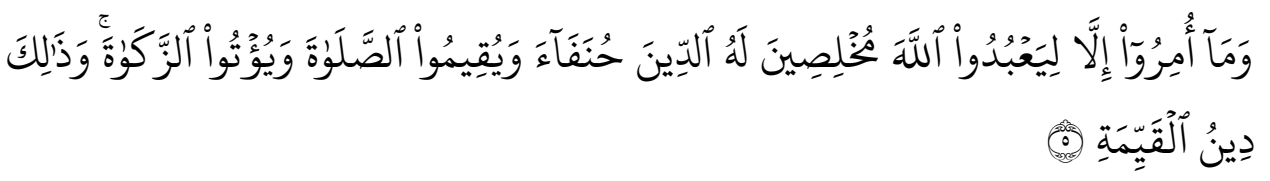

Behavior that reflects the content of the verse is
a. Budi helps to orphans with not an eye to the rewards
b. Karina helps parents work seriously
c. Dandi is saving money for old age
d. Lia prayed in congregation with khusu'
e. Shifa likes to help people who are crossing the street

The criteria are not compiled, namely; Matter is not appropriate to indicators and the options of answer are not homogeneous and logical (material). Indicators asked to indicate an example action of ikblas which contained in QS. Al-Bayyinah verse 5. But the item question just ask behaviors that reflect the content of the verse; The length of answer formula is not the same. Answer a, b, and e is too long, when compared to c and d (construction); Repeating the word has not a sense of unity. Answer of $a, b$ and e repeating the word "aid", "help to" and "help". 
4. Notice the word of Allah below!

The second verse of the Q. S. Al-Kāfirūn mentioned above is.....

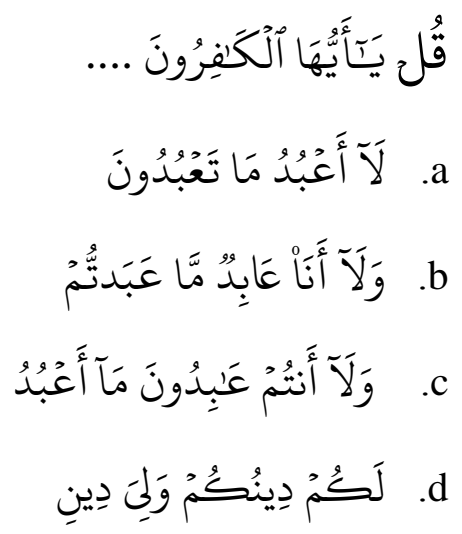

The criteria were not compiled, namely; A matter is not appropriate to indicators. Indicator intends to ask the example of behavior in accordance with the content of Q. S. Ali-Imrān: 159, and Q. S. Ash-Shūra: 38 of democracy, but a matter was asking the second verse of the Q. S. Al-Kāfirūn (suitability indicators); Leads to ytjfthe correct answer. The sentence, "The second verse of the Q. S. Al-Kāfirūn mentioned above is... ", leads to the correct answer (construction); The language used is not in accordance with the rules of Indonesian. The sentence, "Notice the word of Allah below!", Preferably written, “Consider Q. S. Al-Kāfirūn below!”.

5. Consider the following paragraph!
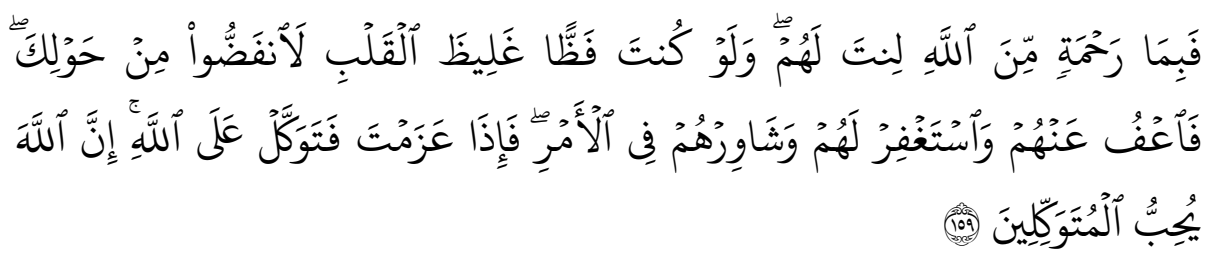

The above verse illustrates that the various conflicts between religion, class and religious understanding in a lot due to the way to resolve differences between them are less precise and thoughtful. The following statement, which does not include the content of Q. S. Ali-Imrān verse 159 is.....

a. Gentle in invites mankind to Islam

b. Forgiving, in order to find solutions to resolve problems

c. Trusts because God loves who put their trust

d. Be patient because God loves who are patient

e. Like deliberation in solving various problems 
The criteria were not compiled, namely; the option is not homogeneous and logical answer (material); a matter is not formulated with clear and concise (construction) and less communicative (language). The phrase "between religion", it should be written "interfaith". The phrase "class and understand the religion" and "how to resolve differences"be confuse to learners.

6. Consider the word of Allah in the Q. S. Al-Baqarah verse 148 below!

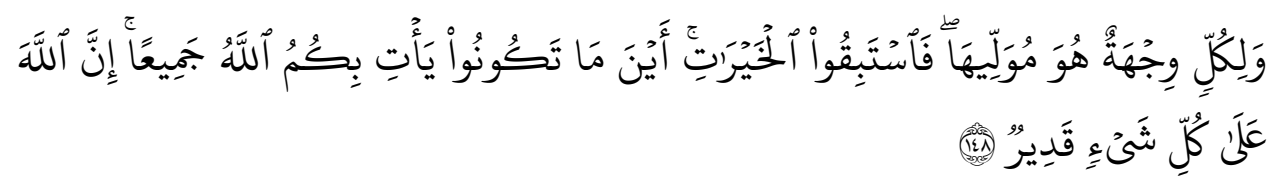

Fill the content of the above verse commands us to ........
a. Learning in earnest in order to be clever
b. Compete in doing good
c. Worshipping in earnest in order to go to heaven
d. Multiply good deeds for the day late
e. Compete to gain top rankings

The criteria are not compiled namely; The length of answer is not the same. Answer of $\mathrm{b}$ shorter than the other answers and contains a double negative statement (construction); The repetition of the phrase is not an integral sense, ie. concept of "competing" and "earnest" (language).

7. Consider Q. S. Ar-Rūm paragraph 41 below!

The true meaning of the verse above is.....

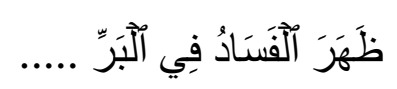
a. Mischief has appeared on land and sea
b. Because of (the meed) that the hands of men
c. That (Allah) may give them
d. A taste of some of their deeds:
e. In order that they may turn back (from Evil).

The criteria were not compiled namely; a matter is not appropriate indicators. Indicators matter intend to ask the learners complete the ayat Q. S. Ar-Rūm verse 41, but the question asked which the correct meaning of the verse 41 of Q. S. Ar-Rūm (material); The length of answer is not the same and a contains has a double negative statement (construction). Answers of a, $\mathrm{c}$, and $\mathrm{e}$ is longer than the $\mathrm{b}$ and $\mathrm{d}$.

8. Consider the QS. Al Araf verse 56 below!

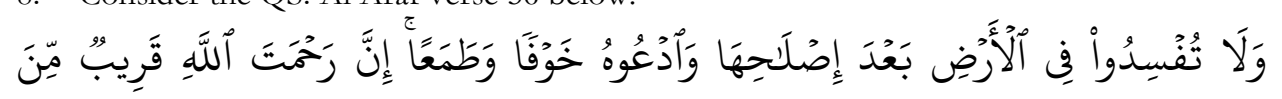




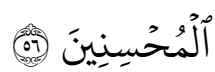

We know that the presence a variety of environmental damage caused by the hands of a human hand, including the disasters that occurred in this country. In accordance with the preceding paragraph, we are commanded by Allah swt. to ...
a. Plant trees that occur greening
b. Create a channel for flood control
c. Do not destroy the earth after Allahrepair
d. Compete to do the best
e. Make the river for agricultural irrigation

The criteria were not compiled namely; the option of answer is not homogeneous and logical (material); the problem (question) is not formulated by clear and concise (construction).

9. Consider the following quote this verse!

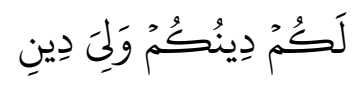

In Q. S. Al-Kāfirūn verse 6 above is a valuable lesson in the context of religious life. Where it recently often occurs conflicts both inter-religious and internal religious community. Through these verses Allah commanded us to ...
a. Rebuked the conflicting because of different beliefs problems
b. Asserts that to you be your Religion, and to me mine
c. Telling people who have another believe to create a new religion's name
d. One time may follow other religions
e. Unlawful compromise with other religions

The criteria were not compiled namely; the answers are not the same length. Answers of $\mathrm{a}$ and $\mathrm{c}$ is longer than $\mathrm{b}, \mathrm{d}$, e (construction); The formulation of the answers is not in accordance with the rules of Bahasa Indonesia. The word "in" at the beginning of the sentence should be omitted. The phrase, "rebuked the conflicting" not-standard and "one-time" should be replaced with "occasional".

10. Consider Q. S. Al-Jumu'ah verse 10 below!

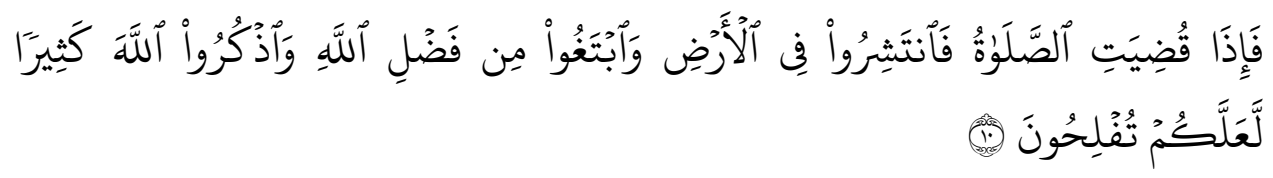

Work ethic must be grown, so that our lives are passionate. The verse commands us to grow the work ethic. In this specific content of the verse is.......

a. Improve human resources by working hard

b. Conducting observations and scientific research to find new theory

c. After his prayer immediately to undertake activities in order to seek ridla by Allah

d. It's okay to develop nuclear, provided for the benefit of mankind 
e. After waking up immediately to go to the office or work in order to get a result

The criteria were not compiled namely; the option is not homogeneous and logical answer (material); The answer is not the same of length (construction). Answer of "a" shorter than b, c, d and e; The answer less communicative, especialy on sentence, "may be developing nuclear, provided for the benefit of mankind". The answer of " $d$ ", should be replaced with, "develop nuclear is okay, provided for the benefit of mankind". Sentence, "after waking up immediately to go to the office or work in order to get a result" in answer of " $\mathrm{e}$ " should be replaced with, "I wake up immediately to go to the office or work in order to be successful" (language).

11. Consider the fragment of Q. S. Yūnus verse 101 below!

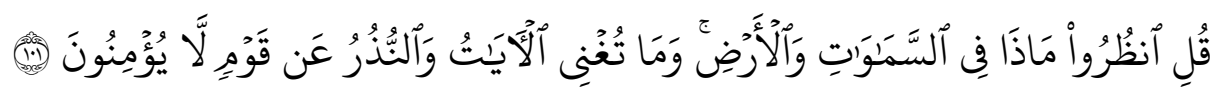

Which is more precise conclusions from the content of the verse above?

a. Allah created the heavens and the earth and everything in it was not in vain

b. Evidence signs of Allah sprawling in the universe

c. The day and night is a law of the universe that is real

d. Human duty conduct exploration of natural resources such as mining

e. Allah has guaranteed the safety of all human beings in this universe

The criteria were not compiled namely; the option is not homogeneous and logical answer (material); The answer formula is not the same length (construction) and less communicative response (language). The question sentence, "Which is more precise conclusions from the content of the verse above?, should be written," the most appropriate conclusion of the content of the verse is...".

12. Consider the fragment of Q. S. Al-Baqarah verse 164 below!

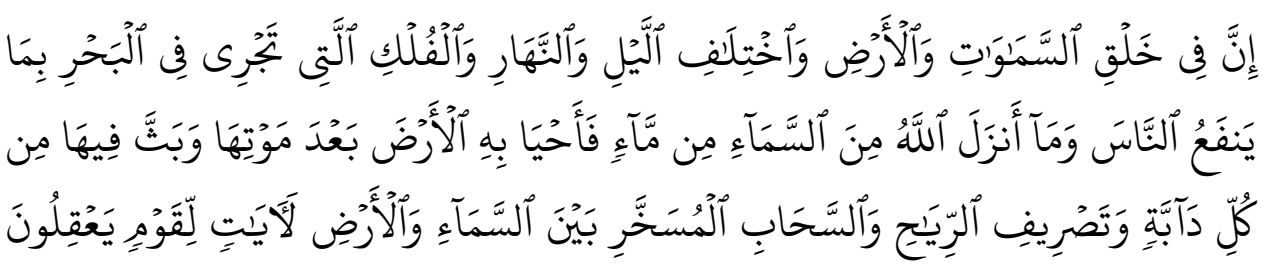

(1120)

Meaning: "Verily in the creation of the heavens and the earth, the alternation of night and day, the ships running in the sea to bring what is useful to man, ...".
a. Indeed Allah has created a boat that can sail in the ocean
b. Man must observe how the circulation of the sun and moon
c. The day and night is a law of the universe that is real
d. Of day and night, ships running to be able to be utilized human
e. Allah will not forgive those who sin 
The criteria were not compiled, namely that the answers are not homogeneous and logical (material); The problem of question is not clear and concise; The length of answer is not the same (construction). Answer of "d" is longer than with a, b, c, and e.

13. Beautiful names are names of Allah. Beautiful names as the realization that Allah does have properties different from His creatures. Among the properties it is Allah Stand Alone. The nature of the Beautiful names are...
a. الرحمن
b. العليمن العين
c. العلى
d. القيوم العبى
e. الحيوم

The criteria are not compiled, namely the formulation is not accordance with the rules of Bahasa Indonesia and less communicative (language).

14. We are encouraged to pray to Allah when people falling sleep, convinced that Allah does not sleep. The nature of Allah is the Most Beautiful Names Living reflected in the following ...
a. الرحمن
b. العليم c.
c. العلى
d. القيوم
e. الحي

The criteria were not compiled, namely that the language used less in accordance with the rules of Bahasa Indonesia and less communicative. The phrase, "the Most Beautiful Names Living reflected in the following", should be written "The nature of Allah is Almighty, the "Supreme Life" on al-Asmā al-Husnā was ..." (language).

15. The number of disasters lately proves that humans are less responsible for the mandate as caliph. Lack of responsibility could be due to the belief in Allah less than the maximum. Listed below are not included in the behavior of people who believe in Allah are ...

a. Humans should be eager to functioning him as caliph

b. Believes that life in this world is closely connected with the afterlife

c. Work harder because the purpose of life is to work

d. Avoid immoral acts because of fear of the consequences in the hereafter

e. Advised mutual advice in truth and patience

The criteria were not compiled, namely that the answers are not homogeneous and logical (material), no matter briefly and clearly formulated and answers are not the same length (construction), and the language used 
less in accordance with the rules of Bahasa Indonesia (language). The sentence, "The lack of responsibility could be due to the belief in God less than the maximum", preferably written, "The lack of responsibility could have been due to the belief in God less than the maximum". The phrase, "below", prefer ably written, "following". The use of the word, "in", should be eliminated; the phrase, "mutual advice", in answer "e", preferably written, "give adviceto each other".

16. Joko is a handsome young man, so many girls who like to be his girlfriend, there is often a wanton woman who likes to tease him and ask him to do nasty, but because Joko a devout Muslim in his religion, then the temptation was always able to refuse, because he believes that all human actions constantly monitored and recorded by the angels ...
a. Gabriel and Michael
b. Rakib and Atid
c. Munkar and Nakir
d. Ridwan and Malik
e. Azrael and Israfil

The criteria were not compiled, namely that the material in question is not in accordance with competence. Expected competencies are showing faith in angels reflection behavior in everyday life, but who asked the angel who supervise and recorded of human actions (suitability of competence); The language used is less in accordance with the rules of Bahasa Indonesia and less communicative. The sentence, "many girls who like to be his girlfriend, often a wanton woman who likes to tease him and ask him to do nasty", ineffective (language).

17. Mr. Abdullah always cautious in attitude and behavior, because believe anything done certainly noted by angels Raqib and Atid. The following questions were included signs of people who do not believe in angels is...
a. Always be optimistic in life
b. Always anxious and frightened
c. Always be alert to act and behave
d. Always keep yourself of misconduct
e. Always draw closer to God

The criteria were not compiled, namely that the answers are not homogeneous and logical (material); the answer is not the same length. Answer " $b$ " is too short compared with the others (construction); Sentence less communicative. The sentence, "The question under which include signs of people who do not believe in angels is...", preferably written, "the statement below does not include the signs of people who believe in angels is..." ( language). 
18. The Qur'an is a way of life for every Muslim. In order to live purposeful and far from straying, then a Muslim has been duly made the Qur'an as legislation. The following are not included wisdom faith in the book of the Qur'an is ....

a. Convinced by completely against the truth of the Qur'an

b. Honor and glorify the Holy Qur'an

c. Understand the contents and run the teachings of the Qur'an

d. All the contents of the book of Allah have the same content

e. Always try and worship according to the instructions book of Allah

The criteria were not compiled, namely that the answers are not homogeneous and logical (material); Problem of question is not formulated clear and concise and do not answer the same length (construction); Sentences were less communicative (language).

19. When Abraham dream to slaughter Ishmael, Abraham then asked Ishmael to actitdream, then Ishmael also told him to fulfill His commands of such. The following behaviors can be emulated by the illustrations, which....

a. Obeying of Allahdespite having sacrificed himself

b. Disobey of Allahbecause there are bad consequences befall

c. We recommend that you ask for permission to his mother

d. Obeying of it but should pick and choose which one is better

e. Waiting for the next command safer

The criteria are not compiled, namely that answers are not homogeneous and logical (material); Problem of question is not clear and concise and the answers are not the same length. Answer " $\mathrm{c}$ " and " $\mathrm{e}$ " is too short if compared with the other answers (construction); Less communicative sentence (language), especialy the phrase, "Here's behavior can be emulated by the illustration".

20. Messengers sent by Allah to warn his people to stay away from despicable deeds. In carrying out its mission apostles were given a revelation as a guide. Here are examples of behaviors that include faith in the Apostle of Allah ...

a. Brought against it because teaching is not in accordance with tradition

b. Politely declined, due in part to its contents taken apostles were not suitable

c. Convinced that the apostle was really a human being

d. Convinced teachings although not see his

e. Convinced, learn and practice the teachings brought

The criteria were not compiled, namely that matter is not clear and concise and the answers are not the same length (construction). Answers b and $d$ is longer than a, c and d; Less communicative sentence (language) that is the phrase "In carrying out its mission apostles were given revelation as a guide". 
21. Onmany verses of the Qur'an that explain about the life in the hereafter, among others explained, whosethe surge is where people who do good, and hell is a place where people who do despicable. The statement below that reflects faith in the end is....

a. Reproduce actgood because it will soon be rewarded

b. No need to actgood because when it's finished already dead human life

c. Life lived freely, because every human being independent citizens

d. Actgood it is measured, calculated, and there is a limit

e. Not fully convinced of the existence of natural barzab

The criteria were not compiled, namely that matter is not formulated with clear and concise and the answers are not the same length (construction). Answer a, d, and e was shorten than b and c. The answer should be relatively the same length so not to direct the learners on the correct answer; Sentence less communicative and repeat the word which not a sense of unity and the language used is not in accordance with the rules of Bahasa Indonesia. The use of the conjunction "on" at the beginning of the sentence question should also be eliminated. Answer a, b. and d repeated the word "act" which is not the unity of sense (language).

22. Every Muslim desirous that his life always get keridlaan from Allah, both in this world and in the hereafter, to make this happen, then every Muslim should be critical and dynamic because Allah will not change the nature fate of people unless they want ...
a. Trying and independent
c. Bend over backwards
e. Change the nature of fate

b. Helping himself

d. Ask for help from others

The criteria were not compiled, namely the answers are not homogeneous and logical (material); Problem of question is not simple and clear (construction); The language used less in accordance with the rules of Bahasa Indonesia (language). Word of "keridlaan", should be written "keridhaan", "change the nature of fate should be written "change what is in their hearts". Writing the word of "Allah", should complete, "Allah SWT" to affirm God of Islam, and the writing of Allah swt must use the comma (,).

23. Consider the following statements?

1) Syamsudin always trying in earnest to achieve goals

2) Amina never hurt when his friend who likes to humiliate him

3) Ali does not like to give a negative statementto something do which other people

4) Aisah not despair, when the year is not accepted at the college he wants

5) Kamaludin always sincere and fervent praying in five (5) times

Which of the above statements relating to the behavior husnuzhan?
a. 1,2 , and 3
c. 3 , 4 , and 5
b. 2,3 , and 4
d. 4,5 , and 1
e. 5,1 , and 2

The criteria were not compiled, namely the sentence is less communicative (language). The sentence, "Which of the above", should be 
replaced "Based on the above statement, which....". The word of "khusuk", should be written, "khusyu".

24. Consider the following statements?

1) Ahmad feel happy in his life despite of his disability since birth

2) In their daily Maemunah always succumb to his poor treatment

3) Maesyaroh willingly accepts the prayers that have not been granted Allah

4) David was a smart kid who always strive to learn and pray to Allah

5) Mahmud convinced of the truth of the contents of the Qur'an given to the Prophet of Muhammad

Which of the above are included husnuzhan behavior in Allah?
a. 1 and 2
c. 3 and 4
e. 1 and 3
b. 2 and 3
d. 1 and 5

The criteria are not compiled, namely the answer in the form of figures not based on cardinal number (construction); Less communicative sentence (language). The sentence, "Which of the above..., preferably written, "Based on the above statement", Which includes busnuzhan behavior in Allah? ".

25. Consider the following story!

Mr. Zakaria often say that unbelievable person, while Mr. Ahmad assume that members of the parlement is not thinking forthe people. Different with Mrs. Amina who often tells charity and it sadaqab to others. Mrs. Nurjanah if story telling never say 'aib' about others, while Mr. Mahmud irritable if his demands were not accepted by his friend.

The nature of husnudzan to others exist in behavior of...
a. Mr. Ahmad
c. Mr. Mahmud
e. Mrs. Minah
b. Mr. Zakaria
d. Mrs. Nurjanah

The criteria were not compiled, namely the matter is not formulated clearly and concisely (construction); Less communicative sentence (language).

26. Taubatan Nasuha is truth repentance, there are four conditions that must be compiled by someone who did Taubatan Nasuha, the following are not included taubatan nasuha, that is...
a. Regret the bad action that have been done in the past
b. Stop sinning and promised do not to repeat it again
c. Abandon bad habits, and do many good action
d. Asked forgiveness to Allahfor all his sins
e. Forward evil do and supplement it with kindness

The criteria were not compiled, namelythe answers are not homogeneous and logical (material); Problem question is not formulated clearly and concisely and provide clues to the correct answer, because it includes understanding taubatan nasüha that can help students answer correctly (construction); Less communicative sentence (language). The phrase, "truth repentance", should be written "repentance truthfully". 
28. Mr. Arman is a bentor driver whosean economic mediocre plus his wife was ill, but Mr. Arman never despair, be diligent shalät, and always full hope to Allah and pray that Allah gives His assist to his family, Mr. Arman attitude at above reflects the behavior is.....
a. King
b. Taubat
c. Istigfar
d. Ridla
e. Syukur

The criteria were not compiled, namely the answers are not homogeneous and logical (material); Problem of question is not formulated clearly and concisely (construction); The language used is not in accordance with the rules of Bahasa Indonesia (language). The word of "but" (in Bahasa Indonesia "tapi"), should be written "but" (in Bahasa Indonesia "tetapi"), word of "prayer" (in Arabic, "sholatt", should be written "prayer" (in Arabic, "shalat"), word of "ridlo" should be written, "ridha", word of "behavior" (in Bahasa Indonesia "prilaku") should be written, "behavior" (in Bahasa Indonesia "perilaku"). The phrase"the behavior" is.., demanding a specific answer because it can be ambiguous. To be more communicative and not confusing, you should say, "are" (in Bahasa Indonesia "adalah") eliminated.

29. Consider the following statements?

1) A child safety expect prayer to Allah for himself

2) A sister was helping clean up school supplies sister

3) A student is being asked to Allah in order to pass their National Exam

4) A child is helping a pedestrian crossing the road

5) A servant'm praying with khusu'

From the statement above, which shows an example of the behavior of the King 'is ...
a. 1 and 2
c. 2 and 4
e. 2 and 5
b. 2 and 3
d. 1 and 3

The criteria were not compiled, namely the matter is not appropriate indicator (indicator). Indicators expect learners can explain the behavior of the king's wisdom in everyday life but are asked instances of behavior of King; The used of the conjunction "of", should be replaced, "based". Writing the word of "Allah", should be written complete "Allah swt" (language).

30. Although eating and drinking is halal and suggested by Allah, but was not allowed to exceed the limit, because of overload will bring harm. Exaggeration to exceed the limit called ...
a. Iz̧är
b. Ikhlās
c.Ikhtiar
d. Tabzir e.Isräf

The criteria were not compiled, namely the answers are not homogeneous and logical (material); Problem of question is not formulated with clear and concise (construction); Less communicative (language). 
31. Consider the following story!

Mr. Sarman never spend of zakät al-mäl and zakät al-fitrab during his life, and the habits of Mrs. Hafsah buying goods are not needed, happyly. Mrs. Rahmi always frugal and careful buying daily necessities of life. While Yusuf was happy take a wudlu and used excessive water. Different with Mrs. Suryani who has a habit vilify her friend, happily.

From the statement above, which shows the action of tabzir is ...

a. Mr. Sarman and Yusuf

b. Mrs. Rahmi and Mrs. Hafsa

c. Mr. Sarman and Mrs. Hafsa

d. Mrs. Rahmi and Suryani

e. Mrs. Hafsah and Yusuf

The criteria were not compiled, namely the answers are not homogeneous and logical (material); Problem of question is not formulated with clear and concise (construction); The language used is not in accordance with the rules of Bahasa Indonesia (language). The use of the conjunction, "of" in the beginning of the question, should be changed to, "based on". The writing says, "Mr. Sarman", supposedly written"Tuan Sarman". The word zakāt, "maal", supposedly written "zakāt mal". The writing says, "berwudlu", supposedly written "berwudhu".

32. Dodi has bad habits, if eaten is never run out, so the rest of the food is wasted. Dodi never conscioushow hard farmers plant rice up into cooked rice. Acts commited Dodi to avoid tabzir behavior is ....

a. Asked to farmers do not to grow rice

b. Food was not delicious to eat should be discarded

c. If you do not run out should be given to others

d. Taking just enough food

e. Eating food which a good for nutrition

The criteria were not compiled, namely the answers are not homogeneous and logical (material); The answer is not the same length (construction). Answers $\mathrm{b}$ and $\mathrm{c}$ is longer than a, d, and e; Used less communicative language (language) and phrase "acts committed Dodi to avoid tabdzir behavior is..."confusing students to answering of question.

33. Consider the following statements!

1) Andika spreading false stories to her friends about Giovani

2) Andreassupposed to her mother that she has lied about his father who went

3) Wibisonoaccused toKhusnulwho stealing a bag and clothes

4) Anita and Novi so happy to talk about the ugliness of Aisah

5) Olivia really like to watch the event on television infotainment gosif

From the statement above, which shows the behavior of backbiting is ...
a. 1 and 2
c. 1 and 4
e. 1 and 3
b. 2 and 5
d. 2 and 5 
The criteria were not compiled, namely that the language used notin accordance with the rules of Bahasa Indonesia (language). The used of the conjunction "from" in the beginning of the question, it should be replaced "by".

34. The relationship of friendship between Alia and Kamila are already running five years, finally had dropped out due to rumors about the evils of Alia are told by Kamila. Consider the statement below!

1) Making hostility between people in social life

2) Can replaced the act of 'amalto others

3) Not going to heaven, according to the Hadith of the Prophet

4) Can be discomfort in social intercourse

5) Damaging around natural environment of human being

From the statement above, which shows the dangers of slander behavior is ....
a. 1,2 and 3
c. 1,2 , and 4
e. 1,3 and 4
b. 2,3 , and 5
d. 2,4 , and 5

The criteria were not compiled, namely the matter is not appropriate indicators. The indicators learners should be could to identify behaviors slander, while it asking about the danger due to the behavior of slander.

35. Observe the table of Islamic Law Resources with it explanation below!

\begin{tabular}{lll}
\hline No & \multicolumn{1}{c}{ Name } & \multicolumn{1}{c}{ Definiton } \\
\hline 1. Al-Qur'àn & a. & $\begin{array}{l}\text { Agreement of the ulama to establish a law based on the Holy } \\
\text { Qur'an and Hadith when at the time of the Prophet } \\
\text { Muhammad did not exist }\end{array}$ \\
2. Al-Hadits & b. $\begin{array}{l}\text { Set of words of Allah which was revealed to the Prophet } \\
\text { Muhammad provides a way of life of mankind }\end{array}$ \\
3. Ijtihad & c. $\begin{array}{l}\text { Equate an event that no legal with legal events because of } \\
\text { the same of illat existed } \\
\text { Trying in earnest to find a law that no legal provisions in } \\
\text { both of Qur'an and Hadith } \\
\text { 4. Ijma' }\end{array}$ & $\begin{array}{l}\text { Everything that comes from the Prophet Muhammad } \\
\text { including words, acts, statutes and ideals }\end{array}$ \\
5. Qiyass &
\end{tabular}

Couple source of Islamic law and the correct understanding is.....
a. 1 and $b$
c. 1 and $\mathrm{d}$
e. 1 and a
b. 1 and c
d. 1 and e

The criteria were not compiled namely the answers are not homogeneous and logical (material).

36. Smoking is not unusual for some community in Indonesia, whereas according to health experts are 360 poisons in cigarettes, while in the Qur'an and Hadith not clearly to call about it haram. These problems indicate.......
a. The importance guided by Qur'an
b. The importance of referring to Hadith
c. The importance to established of law by Ijtihād 
d. The importance of referring to the al Qur'an and Hadith

e. The importance of referring to the al Qur'an and Ijtibäd

The criteria are not compiled namely the material in question was not relevant to competence (material). Competence expect that learners can set itijibäd position as one of the sources of Islamic law, but a matter, through specific illustration, asking the dangers of smoking; The answer is not the same length (construction). Answer $\mathrm{d}$ and e are longer than others; Less communicative language (language). Said, "call", should be written "states". The word "indicate", should be written "show".

37. Every Ramadan, so many Muslims spend of zakät, zakät which be permitted to spend at the beginning, middle, or the end of Ramadan is......

a. Zakāt Mãl

b. Zakät al-Fitrah

c. Zakät Mäl and Fitrah

d. Zakät of Jewelry

e. Zakät of Agriculture

The criteria were not compiled namely, the matter is not appropriate to indicator (indicator). Indicators expecting learners to identify examples of zakät management, while the question asking the impact of slander action. The length of the answer is not the same formulation. Answer " $c$ " is longer than the other answers. Should have relatively equal length answer to give no indication to learners about the correct answer (construction); Less communicative, especialy in "Every Ramadan, so many Muslims spend of rakäat'.

38. Almost every year, Indonesian Hajj pilgrims take a place a top ranks excessively whom to perform the Hajj in Makkah Al-Mukarramah. To perfection of Hajj, pilgrims are required to know the requisite (syarat) and the rukun. Below are including of rukun of Hajj is ....
a. Wuküf at Arafat
b. Mabit in Muzdalifah
c. Leting fly of Jumrah
d. Mabit in Mina
e. Throwing jumrah

The criteria were not compiled namely, the answers are not homogeneous and logical (material); Problem is not formulated with clearly and concisely (construction); Less communicative phrases used (language).

39. Mudhärabah is committing to an agreement between two or more people who one give financial capital and other manage the business with the goal to share of profits. Which including to Mudharabab in the illustration of below is ...

a. The land are cultivated by Mr. Andri, the germ from the owners of land

b. The land are cultivated by Mrs. Olivia, the seed from the tiller 
c. Fajar has a citrus orchard whom treated by Mr. Raiuddin

d. Inez who lend money to Muthia to be traded

e. Amalia has some money and deposited in the bank

The criteria were not compiled namely, the answers are not homogeneous and logical (material); The answer is not the same length(construction). Answer "d" is longer than the others. Less communicative language (language).

40. In mu'amalah, basically, selling is mubāh (be abandoned and may be done) but can turn into haram, if the goods are bought and sold namely alcohol, drugs, or carcasses, because buying and selling of such contains elements of.....
a. Losses
c. Wisdom
e. Mudlārat
b. Avail
d. Benefit

The criteria were not compiled namely, the matter is not appropriate to indicator (suitability indicator). Indicators expected learners can to identify of syirkah example, while the item asking about the legal elements of buying and selling; The language used is less in accordance with the rules of Bahasa Indonesia (language). The used of the conjunction "in" at the beginning statement is not the right question of word. Writing the word "selling", supposedly written "trading".

41. Inthrough of life, someone needs a companion as a partner, therefore marriage is a solution, so that human life is not same to animal life.

Consider the following statement!

1) To obtain legitimate offspring

2) The achievement of reassurance or sakinah

3) Fixed maintain the sanctity of self in relationships

4) To achieve a happy and prosperous family

5) Avoid couples who have less good personality

6) Always asking for consideration of Allah with prayers

From the above statements, which include wedding wisdom is the number...
a. 1,2 and 3
c. 1,2 and 4
e. 2,3 and 5
b. 4,5 and 6
d. 3, 5 and 6

The criteria were not compiled namely, the matter is not appropriate to indicator. Indicators expected learners can specify examples of economic transactions in Islam, while the item asking about the statement that includes wedding wisdom; The language used is less in accordance with the rules of Bahasa Indonesia. The used of the conjunction "in" at the beginning of the sentence should be omitted. The word "from" in the beginning of the question should be replaced "by"; The formulation of the question is less communicative. The use of the word "is" (in Bahasa Indonesia "adalah") not right and "number" should be eliminated (language). 
42. Andi and Tati are two teenagers who are cousins, they love each other and are both intended and promised to married life, but Mr. Qomar father of Tati which is still the younger brother of his mother Andi disagree over their marriage, they both decided to eloped, and married in the birth village of their father and mother, with akad by the prince in the village and witnessed by their families, although without the consent of Tati's father. Andi and Tati wedding was canceled by law because it does not fulfill of marriage rukun (legal ground)...

a. Without the consent of $\ddot{y} \bar{a} b-q a b \bar{u} l$

b. Both are cousins

c. There is no wali (guardian) permission

d. Marring while running

e. No two saksi (witnesses)

The criteria were not compiled namely, the matter is not appropriate indicators. Indicators of question about expecting learners can explain the wisdom of marriage, while the item asking about the cancellation of the marriage according to the provisions of the pillars of marriage. It seems that the use of indicators about the matter to be confused with the number 42 number 43, which learners can demonstrate wedding provisions under Law No. 1 of 1974. The formulation of the question number of 42 should be written according to the indicators about the numberof 43 (indicators); The problem is not formulated with clearly and concisely (construction); Less communicative language (language); The choice of answers are not homogeneous and logical (material). Answer of "d", "marring while running", should be revised.

43. Someone must take responsibility for their off spring not only mentally, but also in terms of the material in the form of inheritance. Islam regulates the division of the estate, which amount is not the same, is also set on the causes someone to gain the estate. Things that cause a person to get the estate is ...
a. Adoption, nasab, and brother of of wet nurse (in Bahasa Indonesia sesusu)
b. Marriage, consanguinity, affinity religion
c. Agreements, marriage, their wills
d. Descent, friendship, marriage
e. Marriage, friendship, and co-religionists

The criteria were not compiled namely, the matter is not appropriate to indicators. Indicators expected learners can show wedding provisions under Law No. 1 of 1974, while the item asking about the things that cause a person to get the estate. Indicators of about 43 confused with the question number of 44 which learners can demonstrate that family members receive the estate. Formulation of the question number of 43 it should be written in accordance with the indicators about the number of 44 (indicators); The problem is not formulated with clearly and concisely (construction); The language used is less communicative; 
44. Saiful had died, he left his inheritance as much as Rp. 54,000,000,-. Heirs consisting of a mother, father, wife, one son and two daughters. The deceased owed Rp 3.250.000,-, bodies maintenance costs Rp 750,000,- and a testament to Rp 2,000,000,- then part 1 girls obtain an inheritance of ....
a. $\quad$ Rp 6.000.000,-
b. $\quad \operatorname{Rp} 6,500,000,-$
c. $\operatorname{Rp} 8.000 .000,-$
d. Rp10.100.000,
e. Rp13.000.000, -

The criteria were not compiled namely, the matter is not appropriate to indicators. The indicators expecting learners can show family members who received the estate, while asking about the division of inheritance. Means the matter is not in accordance with the existing indicators on the lattice. Indicators referred questions about the number of 44 to be confused with the indicators about the number of 45, which learners can identify the wisdom of the law of inheritance. The formulation about the number of 44 should be written according to the indicators about the number of 45 (indicators); Used less communicative language (language).

45. When preaching in Mecca, the Prophet of Muhammad's followers just get a little bit, because there are many people of Quraish were reluctant to follow the teachings despite what brought by the Prophet of Muhammad was right, because arrogance and pride of the Quraysh. The following is the substance of the propaganda of the Prophet of Muhammad in Mecca period is ...
a. Internalizing the values of faith and monotheism
b. Inviting people to unity
c. Developing the freedom and independence of thought
d. Teaching how good politics
e. Teaching how to trade right

The criteria were not compiled namely, the matter is not appropriate to indicators. Indicators of item expecting learners can identify lessons inheritance law, while asking about the substance of propaganda Prophet in Makkah period. Turns indicator referred to by about 45 numbers mixed up with indicators about the number of 46, which learners can deduce the substance of propaganda Prophet in Makkah. Properly formula about number of 45 refers to the number 46 about the indicators (indicators); The length of the answer is not the same formulation. Answer " $b$ " is too short compared with a, d, e. Answer "c" is too long compared with the other answers (construction); Used of less communicative language (language).

46. When Prophet of Muhammad saw, preach Islam in Makkah period of many challenges faced for him, among of others is intimidation and terror inflicted by the infidels of Quraish, among the enemies of the Prophet Muhammad that hinder the preaching still his own uncle who is .... 

a. Abu Sofyan
c. Abu Lahab
e. Umayyad
b. Abu Bakr
d. Muawiyah

The criteria are notcompiled namely, the matter not appropriate to indicator. Indicators of item expected learners can deduce the substance of Prophet's propaganda in Makkah, while the question asking about the enemies of the Prophet Muhammad that blocking message. Apparently, the question about the number of 46 does not exist in a matter of existing indicators in the lattice. Properly formula about number of 46 is replaced with a question that according to the indicators (indicators); The language used is less in accordance with the rules of Indonesian and less communicative sentence (language).

47. The succes of Prophet of preaching in Medina is inseparable from the strategy pursued in preaching. The strategy used in the preaching of the Prophet Muhammad in Medina is as follows, except. ...

a. Establish the mosque as a place of worship and gathering of Muslims

b. Establish friendly relations with non-Muslims through the Medina Charter

c. Reform and religious understanding in order to conform with the development

d. Doing battle to widen the struggle of Islam to various regions

e. Confirmed the brotherhood (Muslim brotherhood) the immigrants and Anshar Kaum

The criteria are not compiled namely, the answers are not homogeneous and logical (material); The problem contains statements that are double and long answer choices are not the same formula (construction); Less communicative sentence (language). There are two words that require two answers that "is" and "exception", the word "is" should be eliminated.

48. The people of Indonesia which was originally a Hindu and Buddhist very responsive to the arrival of Islam, is characterized by the number of people who converted to Islam. Which led to the teachings of Islam quickly accepted by the population in Indonesia is..
a. Easy to convert to Islam, not with a special ceremony
b. Islamic teachings will be readily accepted and in accordance with nature
c. Fertility archipelago and is located very strategically
d. The preachers are widespread throughout the country
e. Support of the kings who had converted to Islam

The criteria were not compiled namely, the answers are not homogeneous and logical (material); The problem is not formulated with clearly and concisely and the answers are not the same length (construction). Answer of "e" is too short compared to the other answer; Used of less communicative language (language). 
49. The development of Islam in Indonesia did not escape from the hard work of the Wali Songo using the methodology and approach were very accommodating. Among the evidence that supports the fact that we can still see today is....

a. Many people are going home during the holidays arrive

b. The number of Islamic parties

c. Establishment of Shariah Banks or Islamic Banks

d. Establishment of mosques as heritage of WaliSongo

e. The rise of people who go to Hajj

The criteria were not compiled namely, the matter is not formulated with clear and concise and the answers are not the same length (construction). Answers of " $\mathrm{b}$ " and $\mathrm{e}$ is too short compared to the other answers. This can lead learners to choose the correct answer.

50. From the figure we can see the history of the past. Note the building image below! The picture is ....

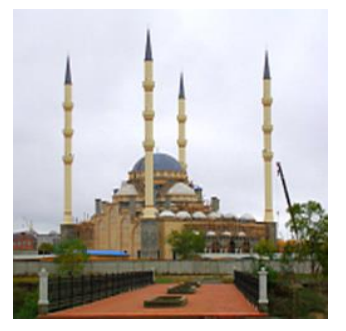
a. Coat of Islamic culture in America
b. Evidence of the development of Islam in Alexandria
c. Symbol of the development of Islam in India
d. Symbol of progress of Islam in Europe
e. The beauty of Al-Hamra Palace

The criteria are not compiled namely, the matter is not appropriate to indicators. Indicators of item expecting learners can show one proof of the development of Islam in the world, while asking about the image of the mosque (indicators); The language used is less in accordance with the rules of Bahasa Indonesia (language). The used of the conjunction "through" at the beginning of the sentence is not quite right.

The findings showed that theoreticaly, there are many items that do not meet such criteria; 1) the subject matter should be clear; 2) choice (content) must answer homogeneous; 3) The length of the answer choices are relatively the same sentence; 4) do not give a clue to the correct answer; 5) choice answers sorted numbers; 6) homogeneous and logical choice answers; 7) do not use a double negative sentences, and 8) the language used raw.

Judging from the aspect of validity could be valid if the measuring instrument can measure to be measured. In the aspect of reliability, an instrument can be said to be reliable if the instrument showed consistent results. Based on the level of difficulty, a good question is a matter that is not too easy and/or difficult. Based on distinguishing, an instrument must be able to distinguish between high-ability learners with low-ability learners. The 
answer key and outwitted must be function properly. For that matter, it should be referred to the Bloom's taxonomy. Accordingly there are six levels of Bloom's taxonomy of cognitive domains, namely the introduction of (C1), comprehension (C2), application (C3), analysis (C4), synthesis (C5), and evaluation (C6) (Mardapi, 2008, p. 93-94).

SUSBN items of PAI in Gorontalo City High Schoolon 2011/2012 year, which the level of C1 cognitive (knowledge)is 9 questions (18\%); C2 level (understanding) are 25 questions (50\%); C3 level (application) are 8 questions (16\%); C4 levels (analysis) are 8questions (16\%); C5 level domain (synthesis) and C6 (evaluation) is $0 \%$. This is indicated that the cognitive problemof Nationally Standardized Examination (SUSBN) in Islamic Religious Education (PAI) on 2011/2012 academic year in high school of Gorontalo City mostly measured cognitive C2 (understanding) aspect.

Based on the contents and format of the test writing about SUSBNPAI in High School at Gorontalo City for the academic year 2011/2012 is valid, because the head of the agency letter head matter is exist, the name of the subjects, classes, day/date, time, work instructions, and grains written clearly and neatly. In the aspect of logical validity of 50 questions, there are 36 items or $72 \%$ according to the indicator. Based on this analysis, there are 14 or $28 \%$ not in accordance with the indicator.

\section{Results of Quantitative Analysis}

Coefficient alpha in SUSBN of PAI in High School at Gorontalo City for the $2011 / 2012$ academic year is 0.819 . Based on these calculations, $80 \%$ of the instrument have compiled reliable. Reference used of reliability quoted from Anastasi (1997, p. 91) states that a minimum of an instrument reliability is 0.80 . Reliability of item which in accordance with the minimum requirements and good content validity achieved scoring 3.21. The size of the index will affect the precision of the reliability of measuring instruments to measured the ability of a test participant. Standard error of measurement can be seen from the SEM values iteman results. SEM for this study is 3.111 mean score of a person is likely to be between 3.1.

From the 50 items, there are eleven items $(22 \%)$ categorized difficult are numbers $1,2,4,5,7,8,10,24,37,44,50$; Thirty one items $(62 \%)$ categorized average namely numbersof $3,6,9,11,12,13,15,16,17,20,22$, $23,25,26,27,28,30,31,32,34,35,36,38,39,40,42$ 43, 46, 49; Eight items $(16 \%)$ categorized easy namely numbers of $14,18,19,21,29,33,41$, and 45 . Those items is good when the index of the category moderately difficulty and not good when the items are within easy or difficult category. Thus, there are $62 \%$ of items are categorized good difficulty level, while $38 \%$ of items categorized not good. This is in accordance with the magnitude of the 
average difficulty index (mean P), namely 0.496 . The coefficient of the mean P 0.494 indicates that the indexis difficult. Items that have difficulty index is not good to be repaired according to that category. When the level of difficulty categorized easy, the matter rectified in order tobe too easy for learners and when the difficulty level is difficult, then the item be fixed in order be not too difficult.

From the 50 items, 27 items (54\%) met the received criteria, namely numbers of $12,13,14,17,18,19,20,21,22,25,26,27,28,29,30,31,32,33$ , 34, 35 38, 40, 41, 43, 45 47, 48; Five items (10\%) met the accepted criteria without revision namely numbers of $2,15,16,42,49 ; 12$ items $(24 \%)$ met the received criteria with a revised namely numbersof $3,5,9,10,11,23,24,36$, $37,39,44,50$. Only six items $(12 \%)$ is not used/discarded namely $1,4,6,7$, 8,46 . This shows that 32 point or $64 \%$ of the index of different items were already functioning and good, namely items of $2,12,13,14,15,16,17,18$, $19,20,21,22,25,26,27,28,29,30,31,32,33,34,35$ 38, 40, 41, 42, 43, 45 47, 48 and 49. While there are 12 items or $24 \%$ which has an index different power needs to be revised. Based on the analysis, it can be said that the difference of item has good power. This is in accordance with the magnitude of difference index average (mean item-tot), that is 0.320 means, questions on this exam has been well classified.

According to Naga (1992, p. 67) as higher the distinguishing pointas greater the difference in scores produced by a group of high and low groups. In other words, the higher of distinguishing point, more and more participants in the other group that can answer the item correctly and getting a little bit low that participants of the group can answer correctly. Therefore, distinguishing point involves dividing the participants into groups of high and low groups.

From the 50 items, 32 items $(64 \%)$ have an effective destractor namely number $1,2,3,4,5,6,9,10,14,15,16,20,22,23,24,25,26$ 27, 28, 29, 30, 31, 33, 34, 35 36, 38 39, 40, 44, 47, 50 and 18 items (36\%) have an ineffective destractor namely number $7,8,11,12,13,17,18,19,21,32,37,41,42,43$, 45, 46 48, and 49. Those items that have destractors are not effective, must be revised in orderbe function effectively. From 50 items SUSBN -PAI in Gorontalo city high school on 2011/2012 academic year there were only two key answers that need to be examined again, namely numbers 4 and 46. The key to the answer that need to be investigated is characterized by the appearance of a warning to check the key on iteman results. This suggests that the true answer needs to be re-examined.

Based on the analysis, there are 21 items (42\%) who have difficulty index and difference was good and fit to criteria. There are 25 points or $50 \%$ of items need to be revised and 4 grains or $8 \%$ category is not feasible. 
Received items, does not need to be revised and can be used in subsequent tests. Items which be revised including different power and uneffetive detractors in order to be accepted. Items that fall, can not be used again in subsequent tests.

\section{CONCLUSION}

Based on the results, SUSBN-PAI on 2011/2012 academic year in high school at Gorontalo City, Celebes, Indonesia have a good quality. But, there are 14 questions which still need to be revised. However, to obtain a good instrument, besides typically, must be tested to the population, the instrument should be analyzed both qualitatively and quantitatively to show up some items have to be revised. The item has revised must be reviewed, when met with tothe criteria, it can be used. Items which compiled to the requirements of the aspects of material, construction, language, reliability, validity, distinguishing features and destractors can be used for final exams. The results of final exams must be reanalyzed to determine the concept or theme that elusive learners and then followed up with remedial which explains the concept that less learners. As a matter which should be standardized nationally, items for the Final Examination of PAI in high school at the city of Gorontalo to be in line with the Regulation of the Minister of Religious Affairs (PMA) No. 16 of 2010 on the Management of Religious Education in schools. Chapter IX Article 26 paragraph (1) and (4) the PMA asserts that the assessment of learning outcomes religious education should be done in the form of standardized nationally. Implementation exam must be guided by the book Guidelines for National Standard School Examination prepared by the Directorate of Islamic Education Ministry of Religious Affairs together with National Education Standards Agency (BNSP).

\section{BIBLIOGRAPHY}

Allen. M. J. \& Yen. W. M., (2002). Introduction to Measurment Theory. Long grove. IL: Waveland Press.

Anastasi, Anne \& Urbina, Susana., (1997). Psycoholological Testing. (Seventh Edition). New Jersey: Prentice-Hall, Inc.

Kemenag, Republik Indonesia., (2011). Pedoman Pelaksanaan Ujian Sekolah Berstandar Nasional (USBN) Tabun Pelajaran 2011/2012 Mata Pelajaran Pendidikan Agama Islam SD, SMP, SMA/SMK. Jakarta: Direktorat Jenderal Pendidikan Agama Islam Direktorat Pendidikan Agama Islam.

Soal Ujian Sekolah Berstandar Nasional Tahun Pelajaran 2011/2012 .

Mardapi, Djemari., (2008). Teknik Penyusunan Instrumen Tes dan Nontes. Yogyakarta: Mitra Cendikia Press. 